\title{
Behavior of Radioactive lodine and Technetium in the Spray Calcination of High-Level Waste
}

\author{
C. A. Knox \\ R. K. Farnsworth
}

August 1981

Prepared for the U.S. Department of Energy under Contract DE-AC06-76RLO 1830

Pacific Northwest Laboratory Operated for the U.S. Department of Energy by Battelle Memorial Institute 
NOTICE

This report was prepared as an account of work sponsored by the United States Government. Neither the United States nor the Department of Energy, nor any of their employees, nor any of their contractors, subcontractors, or their employees, makes any warranty, express or implied, or assumes any legal liability or responsibility for the accuracy. completeness or usefulness of any information, apparatus, product or process disclosed, or represents that its use would not infringe privately owned rights.

The views, opinions and conclusions contained in this report are those of the contractor and do not necessarily represent those of the United States Government or the United States Department of Energy.

\author{
PACIFIC NORTHWEST LABORATORY \\ operated by \\ BATTELLE \\ for the \\ UNITED STATES DEPARTMENT OF ENERGY \\ Under Contract DE-AC06-76RLO 1830
}

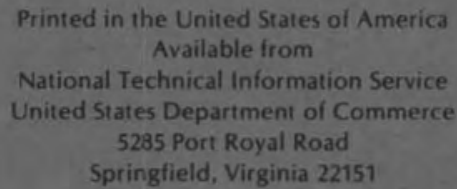

Price: Printed Copy $\$$ $\therefore$ Microfiche $\$ 3.00$

NTIS

*Pages Selling Price

$001-025 \quad \$ 4.00$

$026-050 \quad \$ 4.50$

$051.075 \quad \$ 5.25$

076-100 $\$ 6.00$

$101-125 \quad \$ 6,50$

$126-150 \quad \$ 7.25$

$151: 175 \quad \$ 8.00$

$176-200 \quad \$ 9.00$

$201-225 \quad \$ 9.25$

226-250 $\$ 9.50$

$251-275 \quad \$ 10.75$

276-300 $\$ \$ 11.00$ 
BEHAVIOR OF RADIOACTIVE IODINE AND TECHNETIUM IN THE SPRAY CALCINATION OF HIGH-LEVEL WASTE
C. A. Knox
R. K. Farnsworth

August 1981

Prepared for the U.S. Department of Energy under Contract DE-AC06-76RLO 1830

Pacific Northwest Laboratory Richland, WA 99352 


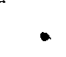




\section{CONTENTS}

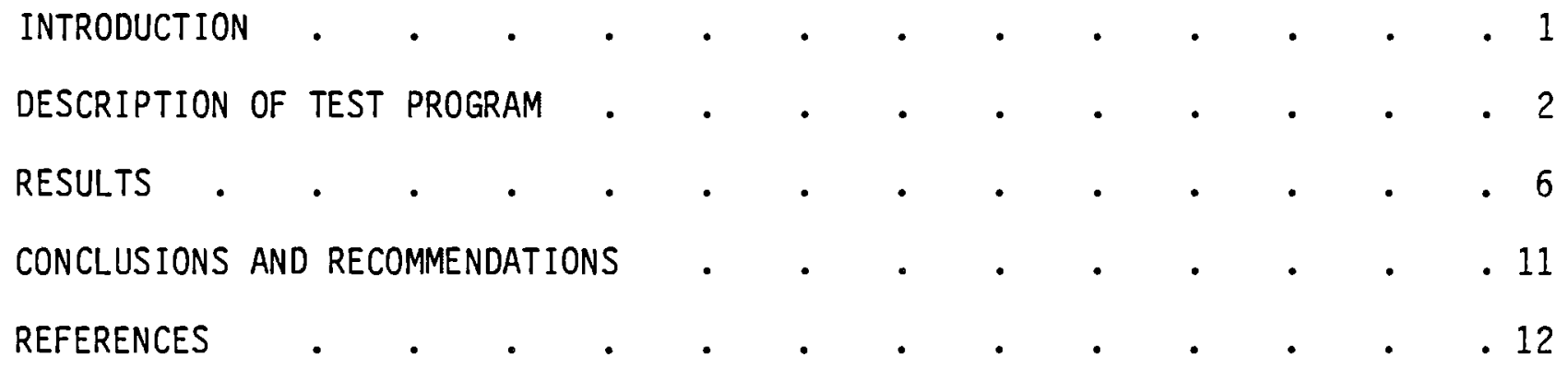




\section{FIGURES}

1 Remote Laboratory-Scale Waste Treatment Facility . . . . . 3

2 Off-Gas Sample Apparatus .

3 Technetium-99 Concentrations in the Venturi Scrubber . . . . 7

4 Technitium-99 Concentrations in the Packed-Scrubber Solution . - 8

5 Iodine-131 Concentrations in the Venturi-Scrubber Solution . . . 9

6 Iodine-131 Concentrations in the Packed-Scrubber Solution . . . 10 


\section{$\underline{\text { INTRODUCTION }}$}

The Remote Laboratory-Scale Waste Treatment Facility (RLSWTF), was designed and built as a part of the High-Level Waste Immobilization Program (now the High-Level Waste Process Development Program) at the Pacific Northwest Laboratory, which is operated by Battelle Memorial Institute for the Department of Energy. In this facility, which is installed in a radiochemical cell, small volumes of radioactive liquid wastes can be solidified, the process off gas can be analyzed, and the methods for decontaminating this off gas can be tested (Hanson, Knox and Berger 1980). Initial operations were completed with nonradioactive, simulated waste solutions (Knox, Siemens and Berger 1981). The first radioactive operations in this facility were performed with a simulated, commercial waste composition containing tracer levels of ${ }^{99} \mathrm{TC}$ and ${ }^{131} \mathrm{I}$. This report describes the facility and test operations and presents the results of the behavior of ${ }^{131_{I}}$ and ${ }^{99} \mathrm{Tc}$ during solidification of radioactive liquid wastes. 


\section{DESCRIPTION OF TEST PROGRAM}

The RLSWTF. (Figure 1) consists of a feed-preparation module, a wastesolidification module and an effluent-treatment module. The wastesolidification equipment used for this operation was a spray calciner. The effluent-control module consists of a number of components that can be operated in different sequences. For this experiment, the process off gas was drawn by vacuum from the spray calciner through stainless steel sintered-metal filters, a venturi scrubber and a packed scrubber. Water was used as the scrubbing solution in the venturi and packed scrubbers.

A nonradioactive, simulated waste solution (Table 1) was prepared and transferred to the feed-preparation module where $13 \mathrm{~L}$ of the solution were spiked with ${ }^{99}$ Tc and ${ }^{131} \mathrm{I}$. Technetium is a weak beta emitter that is difficult to detect in the presence of other radionuclides. Therefore, it was decided to study its behavior in the high-temperature waste-solidification process before the equipment became contaminated with other radionuclides. Iodine was included in the test as ${ }^{131}$ I, which was readily available and would not interfere with technetium analyses due to its short half life $(8.3 \text { days })^{(a)}$.

Due to the small quantity of technetium available, the RLSWTF was started up with the unspiked, simulated waste composition. This unspiked waste was calcined for approximately two hours until all temperatures, pressures, flow rates, etc., had stabilized and the off-gas sampling apparatus had been set up. At this time, the spiked waste was added to the feed, and calcination was continued until the spiked feed was exhausted $(6-1 / 2 \mathrm{~h})$. A sample of this spiked feed was taken for analysis. The "actual" feed composition differed from the nonradioactive, simulated composition due to dilutions with water that occurred when the spiked waste was added and when the feed line was flushed. The results of the feed analysis are given in Table 2.

(a) The iodine was allowed to decay ten half lives before the technetium analyses were started. 


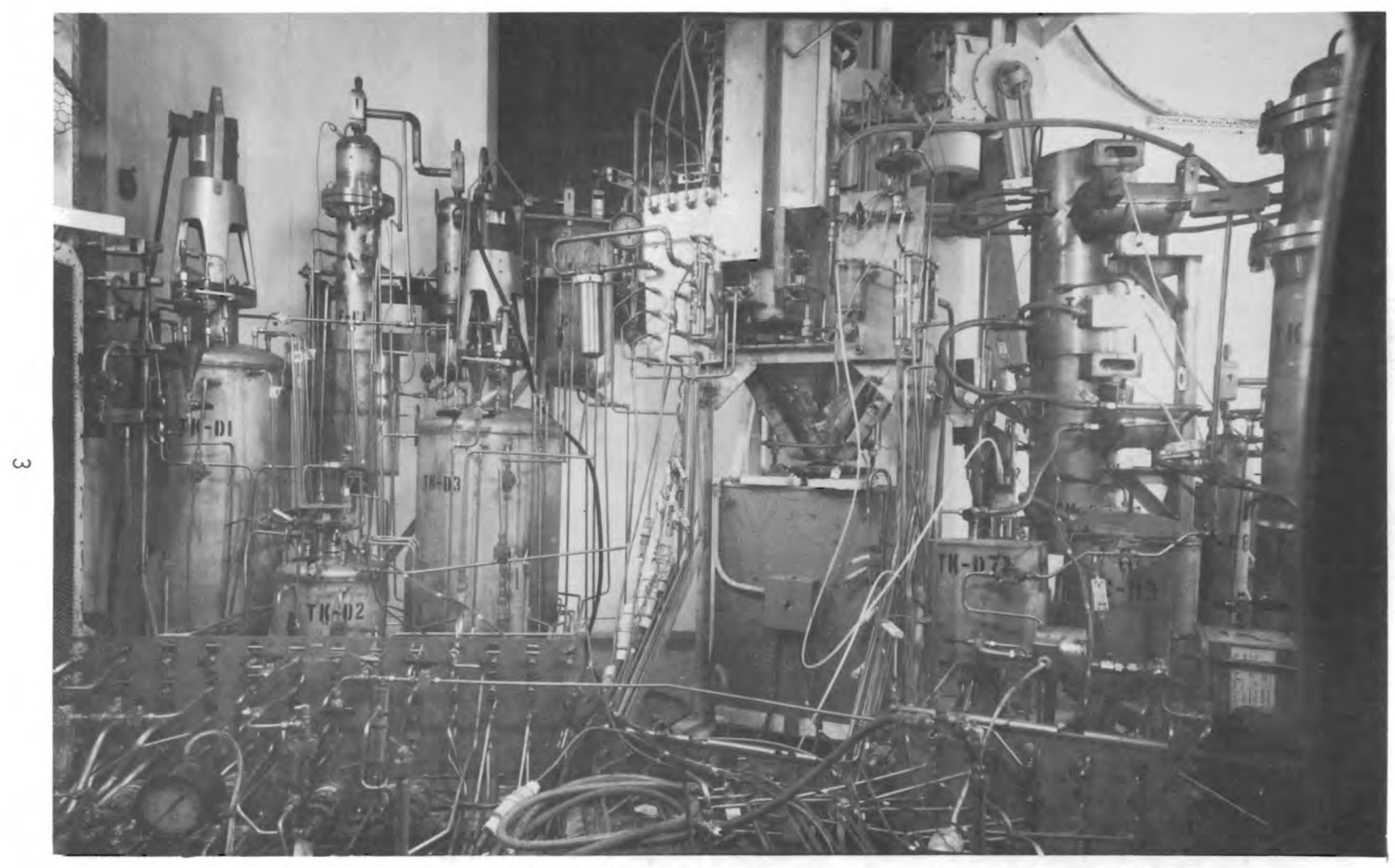

FIGURE 1. Remote Laboratory-Scale Waste Treatment Facility 
TABLE 1. Nonradioactive, Simulated Waste Composition(a)

\begin{tabular}{|c|c|}
\hline Component & Quantity, g/L \\
\hline $\mathrm{Fe}\left(\mathrm{NO}_{3}\right) 9 \mathrm{H}_{2} \mathrm{O}$ & 41.30 \\
\hline $\mathrm{NaNO}_{3}$ & 10.80 \\
\hline Rare earth mix & 07.30 \\
\hline $\mathrm{ZrO}\left(\mathrm{NO}_{3}\right)_{2} 2 \mathrm{H}_{2} \mathrm{O}$ & 03.00 \\
\hline $\mathrm{CsNO}_{3}$ & 02.40 \\
\hline $\mathrm{Ba}\left(\mathrm{NO}_{3}\right)_{2}$ & 02.40 \\
\hline $\mathrm{Ni}\left(\mathrm{NO}_{3}\right) \quad 6 \mathrm{H}_{2} \mathrm{O}$ & 01.60 \\
\hline $75 \% \mathrm{H}_{3} \mathrm{PO}_{4}$ & 00.70 \\
\hline $\mathrm{Cr}\left(\mathrm{NO}_{3}\right)_{3} 9 \mathrm{H}_{2} \mathrm{O}$ & 01.65 \\
\hline $\mathrm{Sr}\left(\mathrm{NO}_{3}\right)$ & 00.60 \\
\hline $\mathrm{Cs}\left(\mathrm{NO}_{3}\right)_{2} 6 \mathrm{H}_{2} \mathrm{O}$ & 00.30 \\
\hline $\mathrm{TeO}_{2}$ & 00.20 \\
\hline $\mathrm{KNO}_{3}$ & 00.10 \\
\hline $\mathrm{Cd}\left(\mathrm{NO}_{3}\right)_{3} 4 \mathrm{H}_{2} \mathrm{O}$ & 00.06 \\
\hline $\mathrm{AgNO}_{3}$ & 00.04 \\
\hline
\end{tabular}

(a) Final $\mathrm{HNO}_{3}$ concentration of $2.06 \mathrm{M}$.

TABLE 2. Spiked Waste Composition(a)

\begin{tabular}{lll} 
Component & & Quantity, g/L \\
\cline { 1 - 1 } $\mathrm{Fe}$ & & 6.2 \\
$\mathrm{Na}$ & & 1.6 \\
${ }^{99} \mathrm{TC}$ & & $.08(\mathrm{Ci} / \mathrm{L})$ \\
${ }^{131_{\mathrm{I}}}$ & & $.0004(\mathrm{Ci} / \mathrm{L})$
\end{tabular}

(a) Specific gravity = $1.1 \mathrm{~g} / \mathrm{cm}^{3}$; nitric acid concentration $=1.38 \mathrm{M}$. 
The feed was fed to the calciner at a constant feed rate of $2 \mathrm{~L} / \mathrm{h}$. During this operation, the venturi scrubber solution was sampled every 30 minutes, and the packed-scrubber solution was sampled every hour. These samples were then analyzed for the ${ }^{99} \mathrm{TC}$ and the ${ }^{131} \mathrm{I}$. Particulate carryover from the calciner was also determined by analyzing these samples for iron. Three samples of the off-gas stream were taken by drawing the off-gas stream through a scrubber solution of $.2 \mathrm{M} \mathrm{NaOH}$ for one hour, as shown in Figure 2. The scrubber solu-

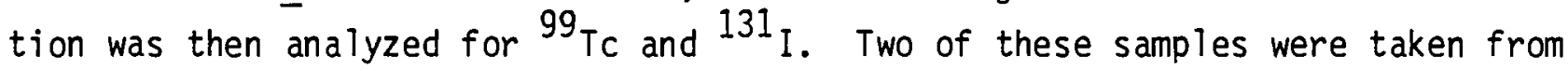
the sample port located downstream of the sintered-metal filters. The other sample was taken downstream of the venturi scrubber.

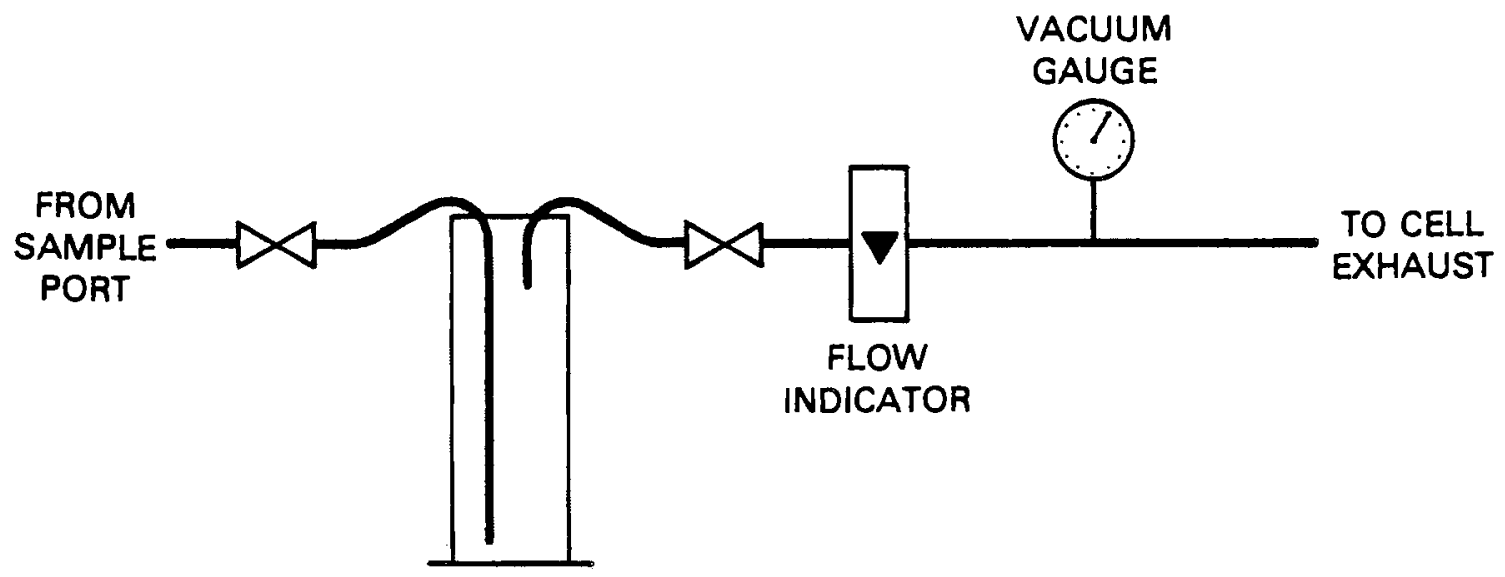

FIGURE 2. Off-Gas Sample Apparatus 


\section{RESULTS}

The venturi scrubber samples were analyzed for iron to determine particulate carryover through the spray calciner's sintered-metal filters. These samples indicated particulate losses of $0.3 \mathrm{wt} \%$, which corresponds to a decontamination factor (DF) of 318, a lower than expected value. However, sinteredmetal filters become more efficient after they have been coated with calcine. Since the filters in this run had not been in service for very long, they may not have accumulated a sufficient coating of calcine. In addition, during this run these filters were routinely blown back with air (although the pressure drop across them had not increased significantly), and this frequent use of filter blowback may have partially removed the calcine coating. In subsequent runs, these filters were blown back only when the pressure drop increased, which indicates excessive calcine buildup. This action should increase the filter operating efficiency so that the expected DFs of 1000 to 3000 are obtained.

The venturi scrubber and packed-scrubber samples were analyzed for ${ }^{99}$ TC. These analyses indicated ${ }^{99} \mathrm{TC}$ losses of $0.15 \mathrm{wt} \%$ from the calciner at $800^{\circ} \mathrm{C}$, which is equivalent to a DF of 500 across the sintered-metal filters. The offgas samples indicated a slightly lower loss $(0.1 \mathrm{wt})$; however, the small difference is probably due to inleakage into the off-gas sampling system. Figures 3 and 4 are the plots of the ${ }^{99} T c$ sample results as a function of time for the venturi scrubber and the packed scrubber. Of the volatilized ${ }^{99} \mathrm{Tc}$ that entered the off-gas system, $83 \%$ was removed in the venturi scrubber (DF $=6$ for ${ }^{99} \mathrm{Tc}$ ).

As was expected, the ${ }^{131}$ I volatilized extensively. Thirty-one percent of the 131 I escaped from the calciner to the off-gas system. Of the volati1 ized ${ }^{131} \mathrm{I}, 52 \%$ was found in the venturi scrubber, $23 \%$ was found in the packed scrubber and $25 \%$ escaped to the building off-gas system where it was removed by the building iodine adsorber. Figures 5 and 6 present plots of the total ${ }^{131}$ I present as a function of time for the venturi scrubber and for the packed scrubber. These results represent DFS for ${ }^{131_{1}}$ of 3,2 , and 2 for the sintered-metal filters, the venturi scrubber and the packed scrubber, respectively. Liquid scrubbers were not effective in removing ${ }^{131}$ I from the off-gas stream. Adsorbents must be used to remove iodine from the off-gas stream. 


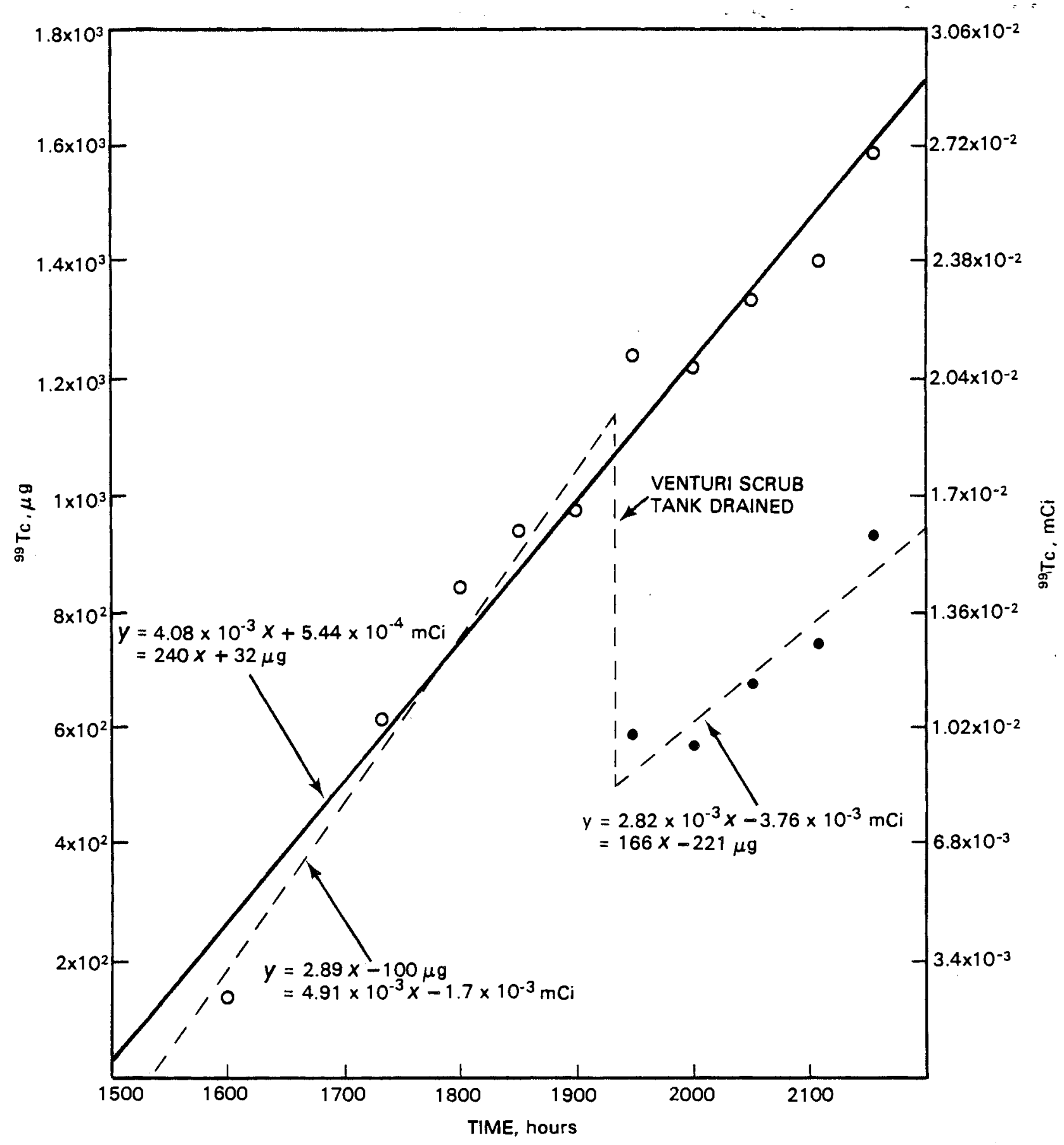

FIGURE 3. Technetium-99 Concentrations in the Venturi Scrubber 


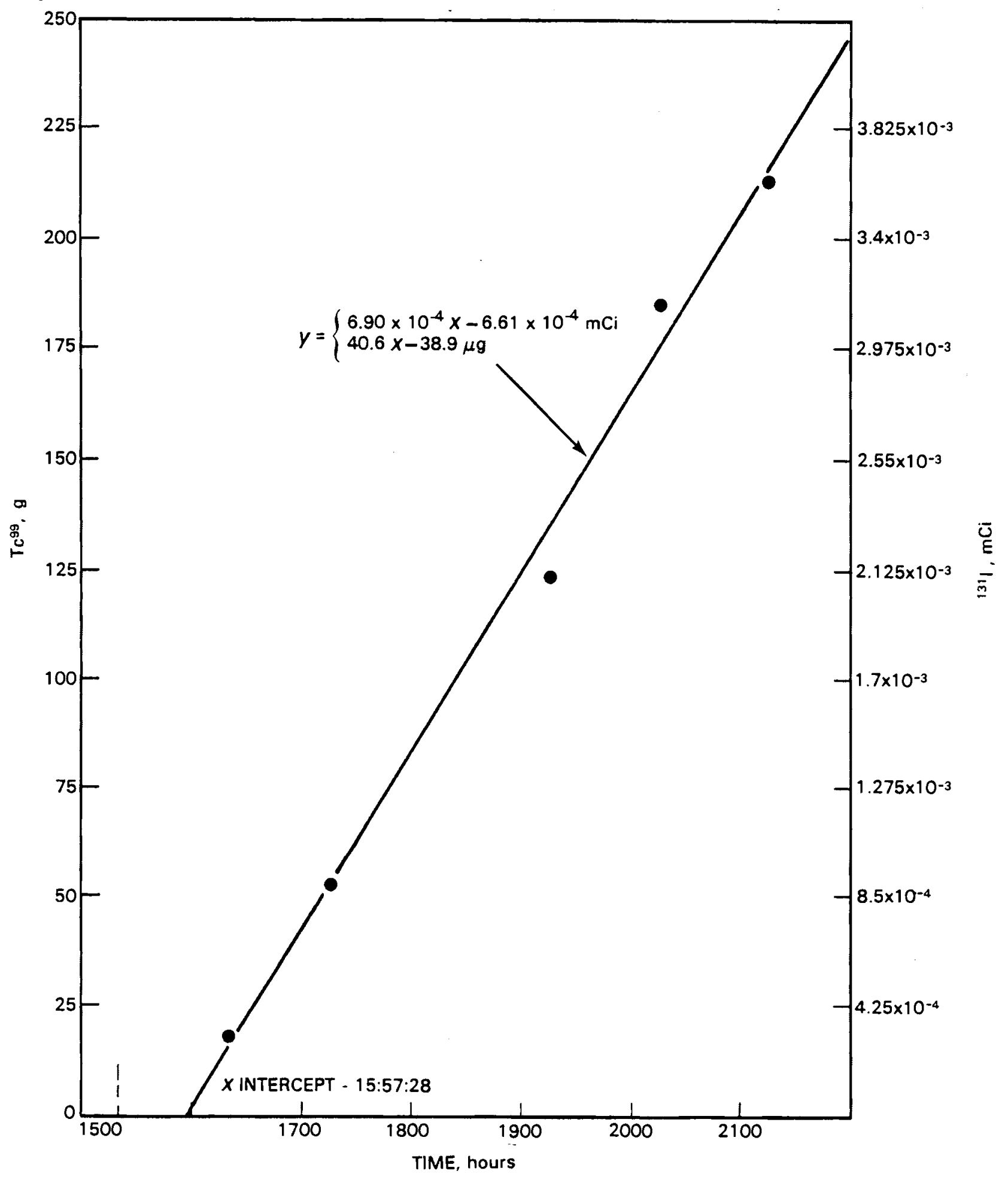

FIGURE 4. Technitium-99 Concentrations in the Packed-Scrubber Solution 


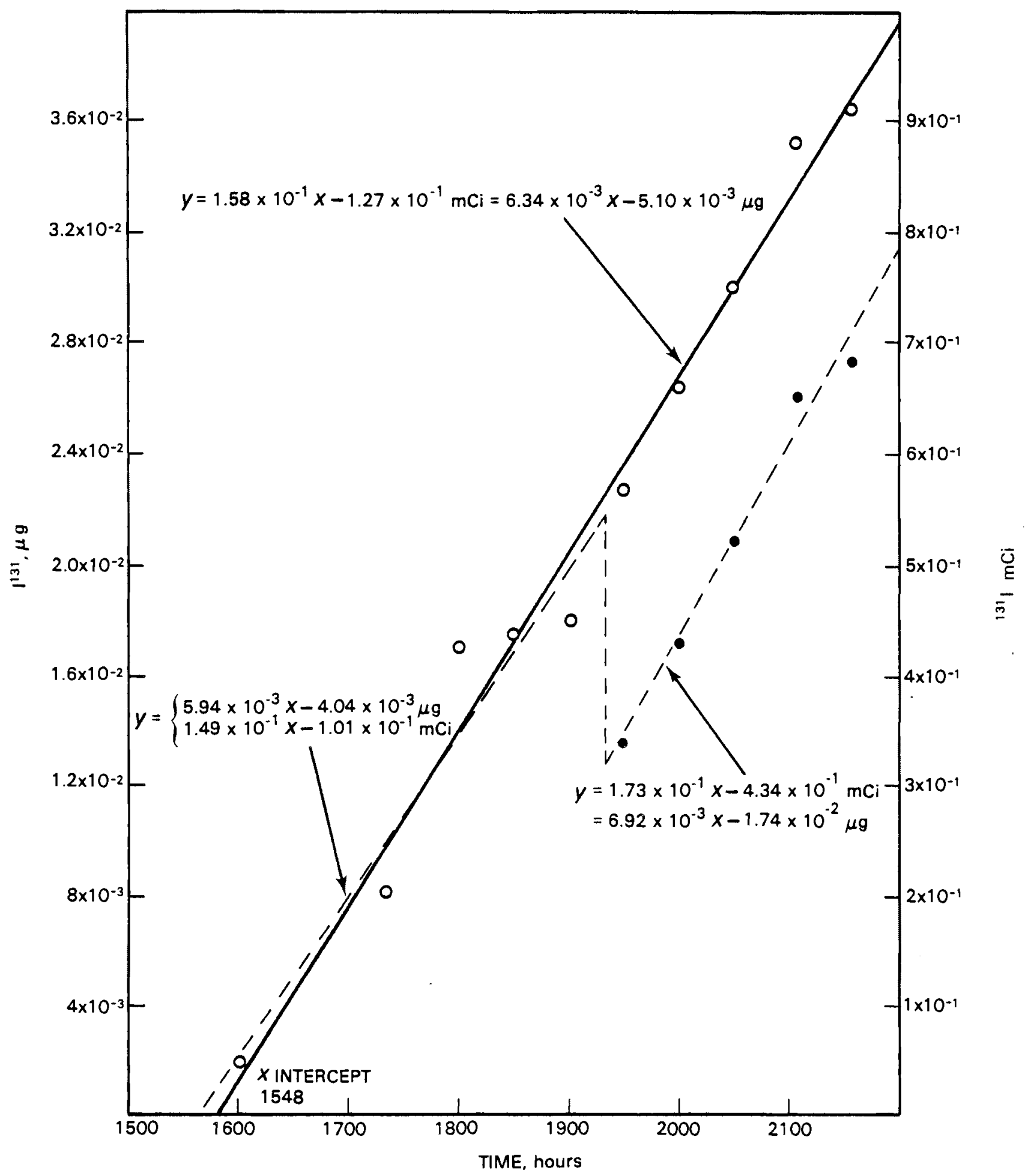

FIGURE 5. Iodine-131 Concentrations in the Venturi-Scrubber Solution 


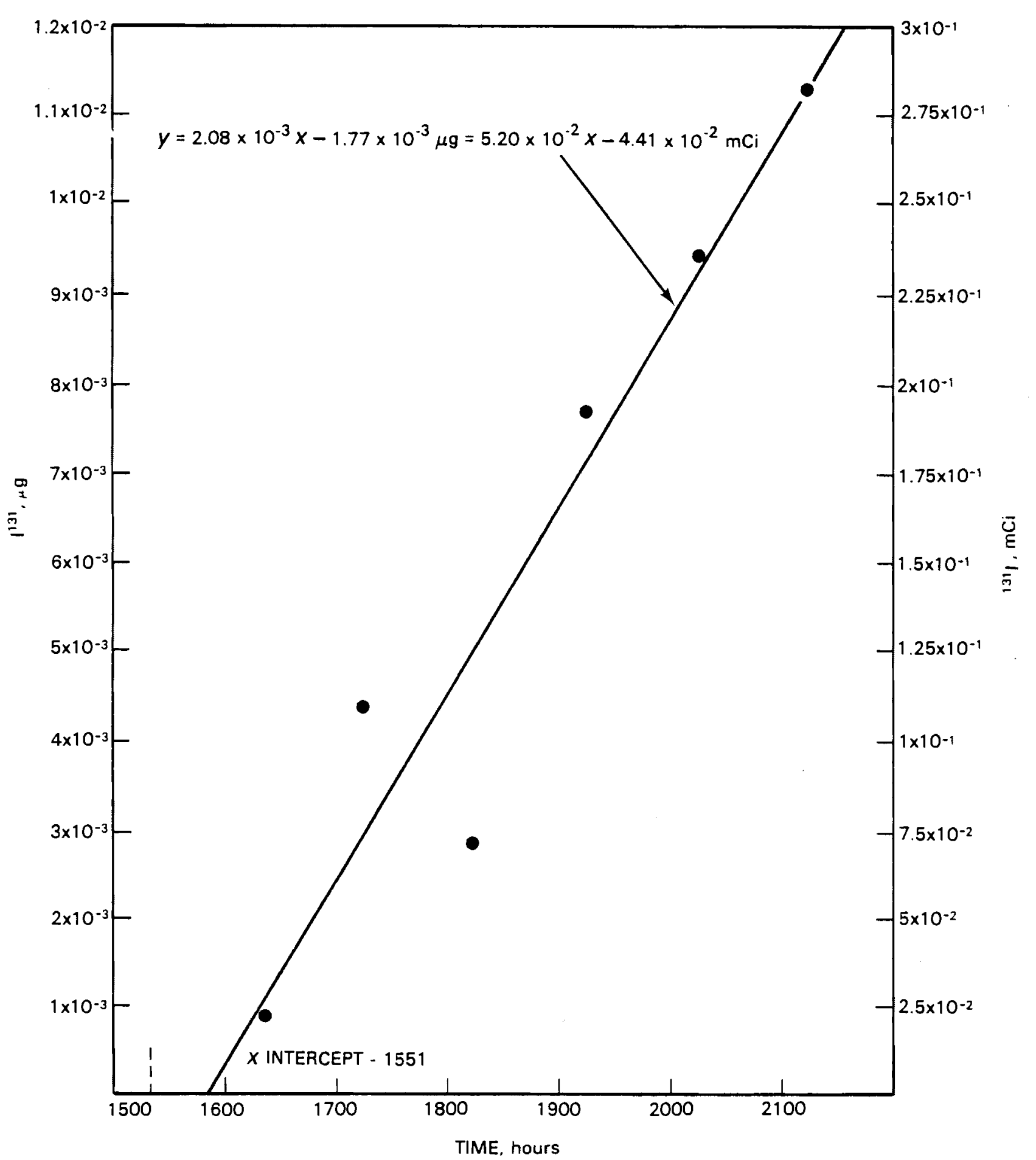

FIGURE 6. Iodine-131 Concentrations in the Packed-Scrubber Solution 


\section{CONCLUSIONS AND RECOMMENDATIONS}

During the spray calcination of commercial high-level liquid waste spiked with ${ }^{99}$ Tc and ${ }^{131}$ I, there was a 0.3 wt\% loss of particulates, a 0.15 wt\% loss of ${ }^{99} \mathrm{Tc}$ and a $31 \mathrm{wt} \%$ loss of ${ }^{131}$ I past the sintered-metal filters. These filters and a venturi scrubber were very efficient in removing particulates and ${ }^{99} \mathrm{TC}$ from the off-gas stream. Liquid scrubbers were not efficient in removing ${ }^{131} \mathrm{I}$, as $25 \%$ of the total lost went to the building off-gas system. Therefore, solid adsorbents will be needed to remove iodine. For all future RLSWTF operations where iodine is present, a silver zeolite adsorber will be used.

The volatility weight percents from this operation on particulate, technetium and iodine losses would be greater for higher-temperature processes and/ or for processes that do not use filters. If the wastes had been vitrified instead of just calcined, the results would have been different. We recommend that these tests be performed for any high-temperature process being considered for high-level-waste immobilization. Similar tests are also needed on other potentially volatile fission products, in particular ruthenium, cesium, and cerium. 


\section{REFERENCES}

Hanson, M. S., C. A. Knox, and D. N. Berger. 1980. Design Features of the Laboratory-Scale Radiochemical Immobilization System. PNL-3027, Pacific Northwest Laboratory, Richland, Washington.

Knox, C. A., D. H. Siemens, and D. N. Berger. 1981. Startup of the Remote Laboratory-Scale Waste-Treatment Facility. PNL-3554, Pacific Northwest Laboratory, Richland, Washington. 
No. of

Copies

\section{OFFSITE}

A. A. Churm

DOE Chicago Patent Group

9800 South Cass Avenue

Argonne, IL 60439

2 R. Y. Lowrey

DOE Albuquerque Operations Office

P.0. Box 5400

Albuquerque, NM 87185

A. L. Taboas

DOE Albuquerque Operations Office

P.0. Box 5400

Albuquerque, NM 87185

S. A. Mann

DOE Chicago Operations and Region Office

Argonne, IL 60439

J. 0. Neff

Department of Energy

Columbus Program Office

505 King Avenue

Columbus, $\mathrm{OH} 43201$

W. E. Mott

DOE Division of Environmental Control Technology

Washington, DC 20545

J. P. Hamric

DOE I daho Operations Office

550 2nd St.

Idaho Falls, ID 83401

J. W. Peel

DOE Idaho Operations Office

550 2nd St.

Idaho Falls, ID 83401
No. of

Copies

J. B. Whitsett

DOE Idaho Operations Office

550 2nd St.

Idaho Falls, ID 83401

C. R. Cooley

DOE Nuclear Waste Management Programs

NE-331, GTN

Washington, DC 20545

G. H. Daly

DOE Nuclear Waste Management Programs

NE-322, GTN

Washington, DC 20545

J. E. Dieckhoner

DOE Nuclear Waste Management Programs

NE-321, GTN

Washington, DC 20545

C. H. George

DOE Nuclear Waste Management

Programs

NE-330, GTN

Washington, DC 20545

C. A. Heath

DOE Nuclear Waste Management Programs

NE-330, GTN

Washington, DC 20545

M. L. Lawrence

DOE Nuclear Waste Management Programs

NE-340, GTN

Washington, DC 20545 
No. of

Copies

D. J. McGoff

DOE Nuclear Waste Management Programs

NE-320, GTN

Washington, DC 20545

S. Meyers/R. Romatowski

DOE Nuclear Waste Management

Programs

NE-30, GTN

Washington, DC 20545

G. Oertel

DOE Nuclear Waste Management

Programs

NE-320, GTN

Washington, DC 20545

A. F. Perge

DOE Nuclear Waste Management

Programs

NE-30, GTN

Washington, DC 20545

R. W. Ramsey, Jr.

DOE Nuclear Waste Management

Programs

NE-301, GTN

Washington, DC 20545

R. Romatowski

DOE Nuclear Waste Management

Programs

NE-30, GTN

Washington, DC 20545

V. Trice

DOE Nuclear Waste Management

Program

NE-30, GTN

Washington, DC 20545

D. L. Vieth

DOE Nuclear Waste Management

Programs

NE-332, GTN

Washington, DC 20545
No. of

Copies

2 S. W. Ahrends

DOE Oak Ridge Operations Office P.0. Box E

Oak Ridge, TN 37830

D. E. Large

DOE Oak Ridge Operations Office P.0. Box E

Oak Ridge, TN 37830

S. G. Harbinson

DOE San Francisco Operations Office

1333 Broadway

Oakland, CA 94612

W. B. Wilson

DOE Savannah River Operations Office

P.0. Box A

Aiken, SC 29801

R. P. Whitfield

DOE Savannah River Operations Office

P.0. Box A

Aiken, SC 29801

J. B. Martin

Division of Waste Management

Nuclear Regulatory Commission

Washington, DC 20555

D. B. Rohrer

Division of Waste Management

Nuclear Regulatory Commission Washington, DC 20555

R. D. Smith

Division of Waste Management Nuclear Regulatory Commission Washington, DC 20555 
No. of

Copies

R. E. Cunningham

Office of Nuclear Safety

Materials and Safeguards

Nuclear Regulatory Commission

Room 562, 7915 Eastern Avenue

Silver Springs, MD 20910

27 DOE Technical Information Center

J. A. Buckham

Allied-General Nuclear Services

P.0. Box 847

Barnwe 11, SC 29812

A. Williams

Allied-General Nuclear Services

P.0. Box 847

Barnwe11, SC 29812

J. W. Bartlett

The Analytical Sciences Corp.

6 Jacob Way

Reading, MA 01867

J. H. Kittel

Argonne National Laboratory

Office of Waste Management

Programs

9700 South Cass Avenue

Argonne, IL 60439

M. J. Steindler/L. E. Trevorrow Argonne National Laboratory

9700 South Cass Avenue

Argonne, IL 60439

W. Carbiener

Battelle Memorial Institute

Office of Nuclear Waste

I solation

505 King Avenue

Columbus, $\mathrm{OH} 43201$
No. of

Copies

Beverly Rawles

Battelle Memorial Institute

Office of Nuclear Waste

I solation

$505 \mathrm{King}$ Avenue

Columbus, $\mathrm{OH} 43201$

Research Library

Battelle Memorial Institute

505 King Avenue

Columbus, $\mathrm{OH} 43201$

R. Maher, Program Manager Waste Management Programs

Savannah River Plant

E. I. Du Pont de Nemours \& Co. Aiken, SC 29801

M. D. Boersma

E. I. Du Pont de Nemours \& Co.

Savannah River Laboratory

Aiken, SC 29801

R. G. Garvin

E. I. Du Pont de Nemours \& Co.

Savannah River Laboratory

Aiken, SC 29801

D. L. McIntosh

E. I. Du Pont de Nemours \& Co.

Savannah River Laboratory

Aiken, SC 29801

A. L. Ayers

$E G$ \& G Idaho

P.0. Box 1625

Idaho Falls, ID 83415

R. Williams

Electric Power Research Institute

3412 Hillview Avenue

Palo Alto, CA 94304 
No. of

Copies

J. L. Larocca, Chairman

Engineering Research and Development Authority

Empire State Plaza

Albany, NY 12223

2 Environmental Protection Agency

Technological Assessment

Division (AW-559)

Office of Radiation Programs

U.S. Environmental Protection Agency

Washington, DC 20460

D. M. Rosenbaum

Office of Radiation Programs

U.S. Environmental Protection Agency

1921 Jefferson Davis Highway

Arlington, VA 22202

J. R. Berreth

Exxon Nuclear Idaho

P.0. Box 2800

Idaho Falls, ID 83401

G. L. Ritter

Exxon Nuclear Idaho

P.0. Box 2800

Idaho Falls, ID 83401

File Copy

Exxon Nuclear Idaho

P.0. Box 2800

Idaho Falls, ID 83401

G. E. Benedict

General Atomics Co.

P.0. Box 81608

San Diego, CA 92138

L. H. Brooks

Gulf Energy and Environmental Systems

P.0. Box 81608

San Diego, CA 92138
No. of

Copies

3 J. Campbe 11

Lawrence Livermore Laboratory

P.0. Box 808

Livermore, CA 94550

J. D. Tewhey

Lawrence Livermore Laboratory

P.0. Box 808

Livermore, CA 94550

R. Roy

202 Materials Research

Laboratory

Pennsylvania State University

University Park, PA 16802

C. J. Kershner

Monsanto Research Corporation

Mound Laboratory

P.0. Box 32

Miamisburg, $\mathrm{OH} 45342$

J. P. Duckworth

Plant Manager

Nuclear. Fuels Services, Inc.

P.0. Box 124

West Valley, NY 14171

R. E. Blanco

Oak Ridge National Laboratory

P.0. Box Y

Oak Ridge, TN 37830

J. 0. B lomeke

Oak Ridge National Laboratory P.0. Box Y

Oak Ridge, TN 37830

D. E. Ferguson

Oak Ridge National Laboratory P.0. Box $Y$

Oak Ridge, TN 37830

3 A. L. Lotts

Oak Ridge National Laboratory

P.0. Box $X$

Oak Ridge, TN 37830 
R. S. Lowrie Oak Ridge National Laboratory P.0. Box Y Oak Ridge, TN 37830

2 A. B. Martin Rockwell International Energy Systems Group 8900 DeSoto Avenue Canoga Park, CA 91304

H. Recht Dept. 737-710

Atomics International Division Rockwe 11 International Box 309

Canoga Park, CA 91304

W. S. Bennett

Rockwell International

Rocky Flats Plant

P.0. Box 464

Golden, CO 80401

Paul Hagen

Chemical Operations

Rockwell International

Rocky Flats Plant

P.0. Box 464

Golden, CO 80401

E. Vejvoda, Director

Chemical Operations

Rockwe 11 International

Rocy Flats Plant

P.0. Box 464

Golden, CO 80401

D. R. Anderson

Sandia Laboratories

Albuquerque, NM 87185

O. E. Jones

Sandia Laboratories

Albuquerque, NM 87185
R. G. Kepler

Organic and Electronic Dept. 5810

Sandia Laboratories

A Tbuquerque, NM 87185

W. Weart

Sandia Laboratories

A lbuquerque, NM 87185

D. E. Harrison

Westinghouse Electric Corp.

P.0. Box 355

Pittsburgh, PA 15230

P. B. Macedo

Keane Hall

Vitreous State Laboratory

The Catholic University of America

Washington, DC 20017

R. G. Post

College of Engineering

University of Arizona

Tucson, AZ 85721

L. L. Hench

Dept. of Materials Science and Engineering

University of Florida

Gainesville, FL 32611

Dr. Hayne Palmour III

2140 Burlington Engineering Laboratories

North Carolina State University Raleigh, NC 27607

F. K. Pittman

3508 Sagecrest Terrace

Ft. Worth, TX 76109 
No. of

Copies

ONSITE

4 DOE Richland Operations Office
P. A. Craig (2)
R. E. Gerton
H. E. Ransom

4 Rockwell Hanford Operations

I. E. Reep

D. D. Wodrich (3)

UNC United Nuclear Industries

F. H. Bouse

Westinghouse Hanford Company

A. G. Blasewitz

76 Pacific Northwest Laboratory

S. M. Barnes

W. J. Bjorklund

H. T. Blair

W. F. Bonner

D. J. Bradley

A. Brandstetter

D. W. Brite

R. A. Brouns

J. L. Buelt

R. L. Bunnell

J. R. Carrell

J. G. Carter

D. B. Cearlock

L. A. Chick

T. D. Chikalla

M. O. Cloninger

R. D. Dierks

G. J. Exarhos

R. K. Farnsworth (3)

J. W. Finnigan

W. J. Gray

C. R. Hann

M. S. Hanson

A. J. Haverfield
No. of

Copies

Pacific Northwest Laboratory (contd)

O. F. Hill

L. K. Holton

J. H. Jarrett

Y. B. Katayama

W. S. Kelly

R. S. Kemper

D. E. Knowlton

C. A. Knox (3)

W. L. Kuhn

L. T. Lakey

D. E. Larson

J. M. Latkovich

R. 0. Lokken

G. B. Long

R. P. Marshall

J. L. McElroy

M. A. McKinney (2)

G. B. Mellinger

J. E. Mende 1

R. D. Nelson

J. F. Nesbitt

R. E. Nightingale

D. E. Olesen

P. J. Pelto

R. D. Peters

L. L. Petkus

A. M. Platt

F. P. Roberts

W. A. Ross

J. M. Rusin

D. H. Siemens

S. C. Slate

C. L. Timmerman

R. L. Treat

R. P. Turcotte

H. H. Van Tuy

B. E. Vaughan

J. W. Wald

J. H. Westsik, Jr.

L. D. Williams

Technical Information (5)

Publishing Coordination VI (2) 